\title{
THE STRUCTURE OF PUBLIC SPENDING ON DRUG POLICY IN CROATIA: WHAT ARE THE PRIORITIES?
}

Sandra ŠVALJEK, Jelena BUDAK

Institute of Economics, Zagreb

UDK: $364.272 .05(497.5)$

$364.65-056.83(497.5)$

Izvorni znanstveni rad

Primljeno: 15. 2. 2013.

The national policy responses to the rising drug problem are effectuated by financing a large set of activities aimed at combating drug abuse. This paper provides an analysis of drug-related public expenditures in Croatia. We have examined the expenditures of public sector institutions in Croatia in the period from 2009 to 2012 . Our main research goal was to identify the total drug-related public expenditures including the unlabelled ones, and to develop the method of estimating and allocating unlabelled expenditures by the type of drug policy program. The estimated total expenditures according to Reuter's drug program division are allocated into prevention, treatment and social reintegration, harm reduction, and law enforcement. The results indicate which types of drug policy programs public authorities in Croatia are really committed to in the sense that those programs absorb the largest proportions of total drug policy expenditures. The methodology applied could contribute to the development of the international methodological standards in this field. The findings are discussed in terms of future monitoring of public expenditures and policy recommendations, in order to facilitate better design programs and activities carried out by policy makers in fighting drug abuse in Croatia.

Keywords: drug policy expenditures, prevention, harm reduction, treatment, law enforcement 


\section{INTRODUCTION}

The latest European Drug Report (EMCDDA, 2013) noted that the drug use in Europe remains high and Croatia fares similarly to the European average (Table 1). The drug toll in terms of overdose deaths reported for Croatia is above the European average.

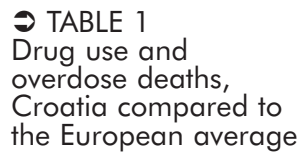

\begin{tabular}{lcc}
\hline & $\begin{array}{c}\text { EU average } \\
(\%)\end{array}$ & $\begin{array}{c}\text { Croatia } \\
(\%)\end{array}$ \\
\hline Cannabis & 16.9 & 15.6 \\
Cocaine & 2.7 & 2.3 \\
Amphetamines & 2.6 & 2.6 \\
Ecstasy & 2.7 & 2.5 \\
LSD & 1.3 & 1.4 \\
Drug-induced deaths & & \\
(per million population) & 18.0 & 19.8 \\
\hline
\end{tabular}

Note: Lifetime prevalence of drug use by adults and overdose deaths per million population aged 15-64, most recent national general population survey 2008 and later, including 24 European countries.

Source: EMCDDA, 2013

Being aware of the devastating consequences of drug use, Croatia is implementing a broad set of measures and activities aimed at combating this problem through its different governmental and non-governmental institutions, as defined in the drug policy strategic documents. Critics of past national strategy documents in Croatia argue that since the 1990s national programs failed due to poor implementation and lack of political will (Sakoman, 2000, 2008). The official

(1) BOX 1

National drug control strategy in the Republic of Croatia 2006-2012 goals drug-related priorities in the period 2006-2012, matching the years observed in our financial analysis, are shown in Box 1.1

The new strategy is comprehensive, focusing on illegal drugs and covers the same five pillars as in the EU strategy: coordination, supply reduction, demand reduction, international cooperation, and information/ research/ evaluation. Its two main goals are: 1) a measurable reduction in drug use, drug addiction and related health and social risks and 2) the measurable promotion of a successful, efficient, scientifically-based application of the law regarding the production and trafficking of drugs and precursors.

Source: Office for Combating Drug Abuse. http://www.uredzadroge.hr/dokumenti/

Although a predominant part of drug policy measures have to be undertaken by the government institutions, which implies that the measures should be financed by the government, it is quite unknown how much the government is spending on dealing with drug problems. For example, the size of government spending intended for carrying out drug policy mentioned in the National drug control action plan in the Re- 
DRUŠ. ISTRAŽ. ZAGREB GOD. 23 (2014), BR. 3 STR. $407-425$

ŠVALJEK, S., BUDAK, J.: THE STRUCTURE OF... public of Croatia in 2012 is extremely small and obviously refers only to the labelled expenditures, whereby it is highly likely that the size of the unlabelled expenditures exceeds this amount. Similarly, even though the main areas of activities aimed at meeting drug policy goals are defined in the strategic documents, it is not known what amount of money the government is spending on each of these areas. The data deficiency described in literature brings up quantification as one of the methodological problems in assessing efficiency of drug-control policies (Greenfield \& Paoli, 2012). In their attempt to examine the five drug-policy approaches, effects and consequences, Strang et al. (2012) concluded there are too few studies providing evidence for effective interventions.

In most countries a lot of attention is devoted to the elaboration of targeted programs aimed at preventing and reducing the use of illegal drugs, in order to lessen their harmful social consequences. Prevention has attracted a much lower proportion of total drug policy expenditures although it is by most stakeholders deemed to be a first priority (Trautmann, Braam, Keizer, \& Lap, 2011). These programs are then implemented by various government institutions either within their activities specifically related to drugs or within their regular activities that encompass not only dealing with drugs but with many other issues. It is less often estimated what amount of taxpayers' money is spent to reduce drug use and related problems, whether the distribution of that money according to the type of program reflects drug policy priorities, and whether the effects of those programs justify public spending. We argue that drug policy could not be formulated and implemented without indicators of its effectiveness, and this paper represents an attempt to get the best possible estimate of the composition of the government's drug policy spending on five areas i.e. programs. Here, we append to the standard four-part division on prevention programs, treatment programs, harm reduction programs and enforcement programs, the fifth type of programs, social reintegration.

According to Reuter (2006), prevention programs are those that are aimed at reducing the number of future drug users through education or reduction of accessibility of drugs for new users. Treatment programs usually include medical and counselling services and are intended to reduce drug use by experienced users. Enforcement programs either reduce the demand for drugs by raising the transaction costs of buying drugs or lower the supply of drugs by making trafficking and production more difficult and risky. Harm reduction programs should reduce the negative consequences of drug use either by preventing harms or making harms more bearable.

Adding to Reuter's division (Reuter, 2006), the social reintegration activity is analysed separately in Croatia. Social re- 
DRUŠ. ISTRAŽ. ZAGREB GOD. 23 (2014), BR. 3, STR. $407-425$

ŠVALJEK, S., BUDAK, J. THE STRUCTURE OF... integration can be understood as part of the treatment in the broader sense, but we considered that insight into public expenditures for social reintegration is important for the drug policy in Croatia. In line with the aforementioned national strategies, the Croatian Government adopted the Project of Social Reintegration of Drug Addicts in April 2007. The project adheres to the treatment program and targets former drug addicts that have successfully completed treatment or rehabilitation in therapeutic communities, out-patient treatment or in prisons. The program includes occupational training, additional education and recruitment incentives to former addicts, helping them to continue education, find a job and start their normal life in society. The side effect of the program is raising awareness of the former drug addicts' inclusion. The program was introduced with an initial 2007 budget of about 12 million kuna and has been implemented by the Croatian Employment Service, NGOs, local government and other stakeholders. ${ }^{2}$ One could expect that since the start of the social reintegration program, the drug policy activities increasingly refer to this aspect of post treatment, and it would be interesting to assess the related public expenditures.

Croatian drug policy expenditures and their structure are assessed for the period from 2009 to 2012, whereas the data for 2012 refer to the expenditures according to the budgetary plan, not according to the actual budget outturn. By getting corresponding figures for four consecutive years, which were also the years of economic downturn, it will be possible to test the stability of both the size and the composition of drug-related government expenditures. Having in mind that most of the similar studies were done for only one fiscal year, the results of our study might be somewhat more insightful.

The paper shows difficulties in developing precise estimates and identifies principal sources of uncertainty regarding drug policy spending. Our main research goal was to identify the total drug-related public expenditures including the unlabelled ones, and to develop a method of estimating and allocating unlabelled expenditures by the type of drug policy program.

The results obtained in this paper could serve to compare the drug spending composition with the ones in the countries for which similar exercises have already been carried out. More interestingly, the results can show whether the programs that are proclaimed to be the highest priority get the most financing. If the same type of estimate would be done in a systematic manner and if the funding would be put in relation with the outcomes of the drug policy programs, this could serve as a useful tool for the assessment of efficiency of the applied 
DRUŠ. ISTRAŽ. ZAGREB GOD. 23 (2014), BR. 3 STR. $407-425$

ŠVALJEK, S., BUDAK, J.: THE STRUCTURE OF... drug policy programs. This work fills the gap between the lack of quantitative measures of drug-control policy effectiveness and blank policy recommendations and helps in setting government priorities (as emphasized in Strang et al., 2012).

The paper is organized as follows. The next section presents a review of the literature on similar studies conducted in other countries. The data and methodology section provides insights in the specifics of gathering information and estimation of labelled and unlabelled expenditures in Croatia by program, while the results are discussed in section four. The last section is concluded with policy recommendations and suggests possible directions of further research.

\section{LITERATURE REVIEW}

The attempts to assess the size and composition of drug policy expenditures are relatively new, not only in Croatia but also worldwide. Some countries like Canada and the United States have a longer tradition of collecting data on drug-related spending, but they mostly concentrate their efforts only on parts of the total public drug expenditures or expenditures pertaining to specialized agencies directly responsible for activities related to drug policy (Vander Laenen, Vandam, De Ruyver, \& Lievens, 2008).

In 2004, Reuter, Ramstedt, and Rigter have developed the guidelines for estimating total drug policy expenditures and categorized them into four groups according to the type of drug policy program they relate to. After that, Ramstedt (2006) and Rigter (2006) provided first estimates of drug policy expenditures for Sweden for 2002 and the Netherlands for 2003, using methodology developed by Reuter and themselves. Their work had an important influence on the further development of research in the area of public spending on drug policy.

Vander Laenen et al. (2008) have identified ten research studies on drug expenditures in Europe. In addition, they have also analysed methodologies used in those studies and showed that the studies were different in many respects. Not only that the information on drug spending in those studies was obtained using different approaches (top-down approach or bottom-up approach), but also the scope of public expenditures they have assessed was different, as well as their classification of drug expenditures. Some studies do not treat illegal drugs separately, but include alcohol and tobacco in the research as well. The Vander Laenen et al. study (2008) could be helpful in further similar research since it clearly defines what constitutes total costs induced by drug problems and points at what should be the subject of public expenditure analysis. ${ }^{3}$ An assessment of drug policy expenditures should 
DRUŠ. ISTRAŽ. ZAGREB GOD. 23 (2014), BR. 3, STR. $407-425$

ŠVALJEK, S., BUDAK, J. THE STRUCTURE OF... concentrate on public drug-related expenditure, but can also include (some degree of) other expenditures related to the consequences of drug use. There are two types of those expenditures: expenditure that is not explicitly aimed at drug policy action, but that indirectly supports the drug policy, and expenditures arising from the loss of productivity and absenteeism in the workplace.

The abovementioned study also stresses the difference between public expenditures exclusively used for initiatives related to the illicit drugs (labelled expenditures) and public expenditures on drug policy embedded in policy projects with broader objectives (unlabelled expenditures), suggesting that both labelled and unlabelled expenditures should be included in drug expenditures assessment. However, "information about unlabelled expenditures, which accounts for the lion's share of drug-related public expenditure, is unavailable" (Costa Storti, De Grauwe, \& Reuter, 2011, p. 324).

European Monitoring Centre for Drugs and Drug Addiction (EMCDDA) is putting an effort in encouraging the European countries to estimate their drug spending and its composition, thus providing internationally comparable data on drug-related spending in the whole European Union. However, so far only eight EU countries tried to use the Reuter categorization (Ireland, France, Luxembourg, Hungary, Portugal, Slovakia, Finland and the UK). The data on composition of drug expenditures they report refer only to the labelled expenditures (EMCDDA, 2008). Since most of the drug-related activities of the public sector are incorporated within larger programs, the labelled expenditures are usually only a minor fraction of the total drug budget. Therefore, the data on the structure of only labelled drug expenditures do not give much information on national policies and government financing in order to reduce drug use.

Due to different methodological approaches, studies on size and composition of drug expenditures cannot be used for direct international comparisons. However, since it is of our primary interest in this paper to get an insight into the structure of drug expenditures in Croatia, we can try to draw some conclusions on the structure of other governments' spending on drug policy, based on those studies that use the Reuter categorization of drug expenditures and assess total (labelled and unlabelled) drug expenditures. The results of those studies are presented in Table 2 below.

Findings of those studies show that law enforcement gets the highest proportion of public funds in most of the countries for which the assessment has been carried out. This proportion ranges from 45 percent in Belgium to 76 percent 
DRUŠ. ISTRAŽ. ZAGREB GOD. 23 (2014), BR. 3 STR. $407-425$

ŠVALJEK, S., BUDAK, J.: THE STRUCTURE OF...

(1) TABLE 2

Results of five studies on drug policy expenditures in Sweden. Belgium is the only country where the assessment has been repeated, so we can compare the results for 2004 and 2008 (Lievens, Vander Laenen, Caulkin, \& De Ruyver, 2012). Interestingly, the structure of drug policy expenditures has changed considerably. The share of spending on law enforcement programs has gone down from 56 to 45 percent, whereas the share of treatment went up by ten percentage points.

Structure of public drug policy expenditures, in \%

Harm

Law en- reduction

Study

Country, year

Prevention Treatment forcement

(other)

Ramstedt (2006)

Sweden, 2002

Rigter (2006)

The Netherlands, 2003

Lievens et al. (2012) Belgium, 2008

Belgium, 2004

Moore (2008)*

Australia, fiscal year 2002-2003

1
2
3.9
3.7
23

$\begin{array}{rr}19 & 76 \\ 13 & 76 \\ 49.4 & 45 . \\ 39.6 & 56.2 \\ 17 & 5\end{array}$

$\begin{array}{rr}76 & 0.1 \\ 76 & 9 \\ 5.1 & 1.9 \\ 6.2 & 0.5 \\ 55 & 4\end{array}$

Note: *For Australia the structure refers to the assessed "proactive expenditure". The study also estimated the "reactive expenditure" or expenditure related to the consequences of drug use. The structure would be different for the sum of proactive and reactive expenditures.

Once again, it has to be emphasized that one should interpret the results of other studies carefully because the results are influenced by the use of different methodologies, and in some cases even political reasons blur the real picture. A strikingly low proportion of spending on harm reduction in Sweden, for instance, is merely a result of the intention of public authorities to turn Sweden into a drug-free society. Consequently, even the idea of harm reduction is rejected, although that does not mean that specific harm reduction programs do not exist in Sweden (Vander Laenen et al., 2008).

\section{DATA AND METHODOLOGY}

The public financing of drug policy is effectuated through specifically designed programs and within the regular activities of various stakeholders. The budget records do not allow for direct capturing of all drug-related public expenditures. Thus funding of particular programs can be found in the budget, yet some activities are "hidden" in other budgetary items. To assess the total drug-related public expenditures, one has to identify both the specified (labelled) expenditures and non-specified (unlabelled) expenditures.

Labelled expenditures/costs are all public expenditures that are specifically drug-related and could be identified as such in the budget by key words in the name of the financed program (e.g. "combating drug abuse", "drug prevention", 
DRUŠ. ISTRAŽ. ZAGREB GOD. 23 (2014), BR. 3, STR. $407-425$

ŠVALJEK, S., BUDAK, J. THE STRUCTURE OF... "social reintegration of addicts", etc.). In distinction to the labelled expenditures, unlabelled costs could not be identified directly in the budget because they refer to the part of the regular activity that is drug-related.

The empirical research is based on data collected within the study of drug-related public expenditures conducted in 2012 in Croatia. The main objective of that study was to estimate the labelled and unlabelled expenditures and to allocate the total drug-related government expenditures in Croatia by public functions. Each ministry and other central government units supposed to be involved in drug policy were asked to specify labelled expenditures from 2009 to 2012 . In the questionnaire that was specifically created for the purpose of the study, all surveyed government institutions (ministries, Croatian Employment Service, Croatian Public Health Institute, Croatian Health Insurance Agency) had to fill out the drug-related public expenditures in national currency (kunas), as specified in their annual budgets. The amounts had been listed separately as executed expenditures for years 2009, 2010, 2011 and 2012 (budget plan only). The institutions had to classify budget expenditures by public functions and by the type of program as well. The described methodology was applied to collect data on labelled expenditures only. Besides using the data on labelled expenditures collected within the study, we have also consulted the state budget data available from the Ministry of Finance.

The central government budget is the main source for public financing of drug policy. We are aware that Croatian counties and cities could have programs and activities financed from the local government budget to combat drug abuse. There are over 570 local government units in Croatia and in this pioneering research it was out of the scope of our work to collect local information on drug policy. This is in line with Moore's (2008) work who did not estimate the local government drug policy expenditures due to the large number of 700 local government units in Australia. Another group of drug-policy implementing organizations are NGOs in Croatia. They were omitted from our analysis as well because of a large number of NGOs involved in some kind of drug-related activities, and more importantly, because they receive funding from ministries. It is impossible to deduct funding to all the NGOs transferred from the central state budget and to distribute these public expenditures by the type of program.

The most demanding task was to identify unlabelled drug-related public expenditures that had to be summed up to the labelled ones to produce total drug-related public expenditures in Croatia, which was the main objective of the study. Since state institutions in Croatia do not have any bud- 
DRUŠ. ISTRAŽ. ZAGREB GOD. 23 (2014), BR. 3 STR. $407-425$

ŠVALJEK, S., BUDAK, J.: THE STRUCTURE OF... get references for the unlabelled expenditures, these costs have been identified indirectly. Within the study, a system of repartition keys ${ }^{4}$ had been developed and applied to the total state unit budget minus labelled costs. For the purpose of the study, calculated unlabelled costs were easily allocated by public functions for ministries and central government units.

Finding out how much of the total drug-related public expenditures in Croatia is spent for prevention, treatment (and social reintegration), harm reduction and law enforcement, became the main research challenge. This work aims to provide solutions on how to estimate related public expenditures by program. The detailed step-by-step analysis, including the structured interviewing method is presented in the next section.

\section{DRUG-RELATED PUBLIC EXPENDITURES IN CROATIA}

We have assessed drug-related public expenditures in Croatia in a three-step analysis. The labelled expenditures of central government in 2009 to 2012 provided in the study of public expenditures and the performance indicators in the field of combating drug abuse in Croatia (Institute of Economics, Zagreb, 2013) are here divided by programs. Next, we have estimated the unlabelled expenditures by program to finally calculate total drug-related expenditures by program for the period from 2009 to 2012. It is worth noting that some central government units have labelled expenditures only (such as Office for Combating Drug Abuse, or Ministry of Defence), others have unlabelled expenditures (e.g. Ministry of Justice) and some have declared both labelled and unlabelled expenditures (e.g. Ministry of Interior).

\section{Labelled Expenditures}

Labelled drug-related public expenditures in nominal amounts by ministries and central government units are presented in Table 3. The total labelled expenditures amount from 70 to 88 million kuna per year. Annual expenditures for prevention (around 20 million kuna) and treatment (around 50 million) are rather stable. The largest individual cost is the prescribed methadone drug for treatment of addicts (40 million kuna in 2011 financed by the Croatian Health Insurance Agency).

Expenditures for social reintegration, harm reduction and law enforcement are much lower and fluctuating largely (Table 4). The annual variations are explained by different systems of program evidence in the budgets rather than by careful planning and design of drug policy programs. Therefore the structure of labelled expenditures is more instructive for the analysis. The last annual data for budget execution are available for year 2011. More than one half of the total labelled drug-expenditures are spent for treatment $(55 \%)$. If the 
(1) TABLE 3

Labelled drug-related expenditures of central government units, 2009-2012 (plan), HRK million

\begin{tabular}{|c|c|c|c|c|c|}
\hline & Central Government Units & 2009 & 2010 & 2011 & $2012(\mathrm{p})$ \\
\hline \multirow[t]{6}{*}{ Prevention } & Ministry of Science, Education and Sport & 0.8 & 0.5 & 0.4 & 1.1 \\
\hline & Ministry of Health & 2.0 & 1.0 & 2.2 & 2.0 \\
\hline & Office for Combating Drug Abuse & 2.1 & 2.0 & 1.7 & 2.1 \\
\hline & Croatian Health Insurance Agency & 15.2 & 15.0 & 18.9 & 18.9 \\
\hline & Croatian Public Health Institute ${ }^{*}$ & 0.0 & 0.0 & 0.0 & 0.0 \\
\hline & Total prevention & 20.1 & 18.5 & 23.2 & 23.9 \\
\hline \multirow[t]{5}{*}{ Treatment } & Ministry of Health & 14.5 & 9.3 & 9.3 & 9.0 \\
\hline & Ministry of Social Policy and Youth & 5.9 & 5.2 & 4.7 & 4.7 \\
\hline & Office for Combating Drug Abuse & 0.2 & 0.2 & 0.2 & 0.2 \\
\hline & Croatian Health Insurance Agency & 26.8 & 37.6 & 39.6 & 28.9 \\
\hline & Total treatment & 47.4 & 52.3 & 53.8 & 42.8 \\
\hline \multirow[t]{4}{*}{ Social reintegration } & Ministry of Health & 0.0 & 0.0 & 0.0 & 0.0 \\
\hline & Office for Combating Drug Abuse & 1.3 & 1.2 & 1.0 & 1.2 \\
\hline & Croatian Employment Agency & 0.4 & 0.4 & 0.4 & 1.1 \\
\hline & Total social reintegration & 1.5 & 1.6 & 1.4 & 2.3 \\
\hline \multirow[t]{4}{*}{ Harm reduction } & Ministry of Health & 0.0 & 3.5 & 5.4 & 5.5 \\
\hline & Office for Combating Drug Abuse & 0.4 & 0.4 & 0.3 & 0.4 \\
\hline & Ministry of Defence & 0.0 & 0.0 & 0.0 & 0.0 \\
\hline & Total harm reduction & 0.4 & 3.9 & 5.8 & 5.9 \\
\hline \multirow[t]{3}{*}{ Law enforcement } & Ministry of Interior & 0.0 & 7.8 & 3.4 & 0.0 \\
\hline & Office for Combating Drug Abuse & 0.2 & 0.2 & 0.1 & 0.2 \\
\hline & Total law enforcement & 0.2 & 8.0 & 3.5 & 0.2 \\
\hline
\end{tabular}

social reintegration is added to the treatment according to Reuter's categorization, the costs of treatment in the broader sense make around 58 percent of the total labelled expenditures. with 8 percent, and law enforcement with only 4 percent. Harm reduction contributes to total labelled expenditures

Note $* 0.0$ means that there is some drug-related spending but its size is below 0.1 HRK million.

Source for original data: project Public expenditures and the establishment of performance indicators in the field of combating drug abuse in the Republic of Croatia, EIZ, 2013.

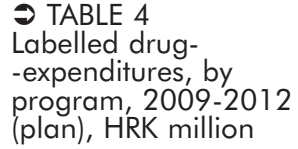

\begin{tabular}{lrrrr}
\hline Program & 2009 & 2010 & 2011 & $2012(\mathrm{p})$ \\
\hline Prevention & 20.1 & 18.5 & 23.2 & 23.9 \\
Treatment & 47.4 & 52.3 & 53.8 & 42.8 \\
Social reintegration & 1.5 & 1.6 & 1.4 & 2.3 \\
Harm reduction & 0.4 & 3.9 & 5.8 & 5.9 \\
Law enforcement & 0.2 & 8.0 & 3.5 & 0.2 \\
Total labelled expenditures & 69.6 & 84.3 & 87.7 & 75.1 \\
\hline
\end{tabular}

Source for original data: project Public expenditures and the establishment of performance indicators in the field of combating drug abuse in the Republic of Croatia, EIZ, 2013. 


\section{Unlabelled Expenditures}

In a given period, total unlabelled expenditures range from 621 to 650 million kuna. As expected, they largely surmount labelled ones because, in Croatia, budget planning and evidence by programs is still lacking. Therefore, most drug-related measures are incorporated into the regular activities of ministries and central government units. Ministry of Interior and Ministry of Justice have the highest estimated unlabelled expenditures and account for about 90 percent of the total

(1) TABLE 5

Unlabelled drug-related expenditures of central government units, 2009-2012 (plan), HRK million unlabelled expenditures (Table 5). The nominal amounts of unlabelled costs were estimated in the study of public expenditures (EIZ, 2013) and categorized by institutions. However, institutions were not able to classify unlabelled expenditures by the type of program.

\begin{tabular}{lrrrr}
\hline Central Government Units & 2009 & 2010 & 2011 & $2012(\mathrm{p})$ \\
\hline Ministry of Interior & 280.4 & 277.5 & 289.0 & 283.2 \\
Ministry of Science, Education and Sport & 5.1 & 4.7 & 4.8 & 4.5 \\
Ministry of Justice & 287.2 & 283.4 & 294.3 & 273.0 \\
Ministry of Social Policy and Youth & 0.7 & 0.7 & 0.7 & 0.7 \\
Ministry of Finance-Customs Administration & 10.5 & 10.6 & 10.1 & 10.1 \\
Croatian Health Insurance Agency & 52.1 & 51.8 & 51.2 & 49.8 \\
Total unlabelled expenditures & 636.0 & 628.7 & 650.1 & 621.3
\end{tabular}

Source for original data: project Public expenditures and the establishment of performance indicators in the field of combating drug abuse in the Republic of Croatia, EIZ 2013.

In order to allocate the amount of unlabelled expenditures to each program, we have estimated the structure of unlabelled expenditures by the type of program. Our estimates are made upon the information gathered in semi-structured interviews conducted with representatives of each ministry and central government unit. Throughout the interviews we have collected experts' opinions about the type of their regular activities that might be related to combating drug abuse (Box 2).

The unlabelled expenditures of the Ministry of Interior are partially related to the activities of regular patrolling. Merely the presence of the police on the streets has strong prevention effects. Many random traffic controls, for example, result in discovering drug abuse and most of the expenses that cannot be specified relate to law enforcement. Background work of the Ministry of Interior staff supporting the more visible actions against crime is costly but almost entirely related to law enforcement. This reasoning led us to estimate that 80 percent of unlabelled expenditures of the Ministry of Interior should be allocated to law enforcement and 20 percent to prevention. 
Data in exploratory research were collected using semi-structured interviews. Experts invited to interviews were selected upon recommendation and track record of cooperation with the Office for Combating Drug Abuse of the Government of the Republic of Croatia. The refined selection criteria was to have a representative pool of experts representing each institution, comprised of at least one budgetary / financing expert, one drug-related program expert and one "hands-on" implementation expert. Prior to interviews, interview guides were developed for each of the expert groups. Institutions were grouped according to the similarities of their drug-related activities, e.g. judiciary group was formed of the representatives from the Ministry of Justice, and State Attorney's Office. Prior to the interviews, the invited experts were provided with the previously collected data on labelled expenses reported in their institutions' budgets 2009-2012. For each institution, the preliminary indicators to estimate unlabelled expenditure were listed. Questions developed in the interview guides were: Please describe your institution's activities that might be related to drug control? Which activity do you consider to fall into the prevention, treatment, harm reduction, law enforcement, and social integration? What portion of your institution's regular activity could be attributed to each program, and why? In the course of the interview questions were directed toward exploration of topics related to assessing and allocation of activities to a particular program.

There were two interviewers present at each interview. One asked questions, while the other one made notes, and roles changed in consecutive interviews. Afterwards, interview notes were transcribed and sent to interviewees for verification and amendments. Verified notes were used for estimating the structure of unlabelled public expenditures by the type of program.

Involvement of several researchers in the process of interviews and their triangulation eliminated researcher's bias and positively affected research validity (Berg, 1995; Miles \& Huberman, 1994; Denzin, 1978; Silverman, 2006). All interviews were conducted face to face. The average duration of interview was 90 minutes. The total of 88 persons was consulted in the whole process, among them 27 in the direct semi-structured interviews held in November 2012. The list of participants, their positions, and dates of interviews are available in Budak, Jurlina Alibegović, Slijepčević, \& Švaljek, 2013, p. 77-80.

(1) BOX 2

Method of semi-structured interviews used to estimate the structure of unlabelled expenditures
Ministry of Science, Education and Sport's unlabelled drug-related expenditures should entirely be allocated to prevention. Namely, the Ministry and its Education and Teacher Training Agency define the primary and secondary schools curriculum and class hour norms to teach students about the drug abuse problem. This program is incorporated into regular class hours and therefore financed from the state budget.

As far as Ministry of Justice and State Attorney are concerned, their unlabelled expenditures relate to the judicial prosecution and imprisonments for the drug-related crimes, therefore to law enforcement. Unlabelled judiciary costs encompass the cost of drug-abuse cases prosecuted by the State Attorney and the courts. The total costs of prisons in Croatia include the costs of imprisonment of persons sentenced for drug offences. It is worth noting that all drug-addicted prisoners, regardless for which crime they were sentenced, receive medical treatment in prisons. Since such services are provided by external health care staff, these expenditures are evidenced under the health sector expenditures as treatment. 
DRUŠ. ISTRAŽ. ZAGREB GOD. 23 (2014), BR. 3 STR. $407-425$

ŠVALJEK, S., BUDAK, J.: THE STRUCTURE OF...

(1) TABLE 6

Estimated structure of unlabelled public expenditures by the type of program
The Croatian Health Insurance Agency funds are used for treatment of drug use disorders and harm reduction. We have estimated that the major part, 80 percent of unlabelled health sector public expenditures, should be assigned to treatment. The unlabelled expenditures relate to the out-of-hospital medical treatment of opioid-dependent patients, such as visits to the primary healthcare doctor's office in order to receive prescribed methadone therapy. It also includes the unlabelled costs of hospital treatment of addicted patients. Distribution of clean needles, free HIV testing and other harm reduction programs also make up part of the unlabelled health public expenditures, in the estimated share of 20 percent.

Unlabelled expenditures of the Ministry of Social Policy and Youth are mostly allocated to social reintegration programs because they consist of help from the social welfare centres and family centres who work with persons with drug addiction problems. Besides working directly with persons with drug problems, experts in the centres provide assistance to persons and families facing other problems (alcohol, abuse, etc.). By helping families, especially children in difficult life situations, centres indirectly prevent them from using drugs as well. Therefore, the estimated allocation of unlabelled social care expenditures is $90 \%$ for treatment and $10 \%$ for prevention.

One of the regular activities of Customs Administration is the inspection of persons and goods crossing the border. As in the case of the police, the very presence of customs control at border passes prevents drug trafficking, especially taking into account that customs supervise the imports, final usage and transit of chemicals that might be used as precursors for drug production. Seized smuggling and drugs confiscated by the customs in cooperation with the border police reduces the quantity of drugs on the illegal market. The unlabelled drug-related expenditures of customs are allocated 80 percent to law enforcement and 20 percent to prevention.

\begin{tabular}{|c|c|c|c|c|c|}
\hline Central Government Units & Prevention & Treatment & $\begin{array}{l}\text { Social re- } \\
\text { integration }\end{array}$ & $\begin{array}{r}\text { Harm } \\
\text { reduction }\end{array}$ & $\begin{array}{r}\text { Law } \\
\text { enforcement }\end{array}$ \\
\hline Ministry of Interior & $20 \%$ & & & & $80 \%$ \\
\hline $\begin{array}{l}\text { Ministry of Science, Education } \\
\text { and Sport }\end{array}$ & $100 \%$ & & & & \\
\hline Ministry of Justice & & & & & $100 \%$ \\
\hline Croatian Health Insurance Agency & & $80 \%$ & & $20 \%$ & \\
\hline Ministry of Social Policy and Youth & $10 \%$ & & $90 \%$ & & \\
\hline $\begin{array}{l}\text { Ministry of Finance-Customs } \\
\text { Administration }\end{array}$ & $20 \%$ & & & & $80 \%$ \\
\hline
\end{tabular}

The above described estimates of the structure of unla- 
DRUŠ. ISTRAŽ. ZAGREB GOD. 23 (2014), BR. 3, STR. $407-425$

ŠVALJEK, S., BUDAK, J.: THE STRUCTURE OF...

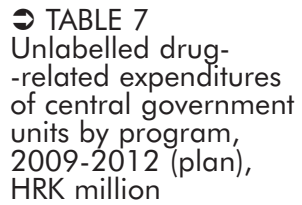

empirical research and surveying practices of government units in drug-related public financing providing unique evidence on the structure of unlabelled public expenditures by program. The results are used to allocate the total nominal amount of unlabelled drug-related expenditures (as previously shown in Table 5) by program. In the next step we have applied the percentages for each central government unit and distributed the amount of unlabelled expenditures accordingly.

\begin{tabular}{lrrrr}
\hline Program & 2009 & 2010 & 2011 & $2012(\mathrm{p})$ \\
\hline Prevention & 63.3 & 62.4 & 64.7 & 63.2 \\
Treatment & 41.7 & 41.4 & 40.9 & 39.8 \\
Social reintegration & 0.6 & 0.6 & 0.6 & 0.6 \\
Harm reduction & 10.4 & 10.4 & 10.3 & 10.0 \\
Law enforcement & 519.9 & 513.9 & 533.6 & 507.7 \\
Total unlabelled expenditures & 635.9 & 628.7 & 650.1 & 621.3 \\
\hline
\end{tabular}

The unlabelled expenditures summed up by each program are shown in Table 7. Due to the estimation methodology of unlabelled expenditures and the identical coefficients applied to allocate unlabelled expenditures to programs, the amounts and structure of the unlabelled expenditures are stable in the whole period. The most considerable unlabelled expenditures are for law enforcement (82 percent of unlabelled expenditures in 2011), due to regular activities of policing and criminal prosecution of drug dealers. The unlabelled expenditures for treatment and social integration together make up only 6 percent of total unlabelled costs, because they are mainly evidenced as labelled ones. Unlabelled expenditures for prevention are about 10 percent of the total unlabelled expenditures (data for 2011).

\section{Total Expenditures}

Finally we have summed up the labelled and estimated unlabelled drug public expenditures by program (Table 8 ). The total drug-related expenditures in Croatia range from 705 million kuna in year 2009 to 697 million planned for year 2012. The total expenditures reached their maximum in year 2011 (738 million kuna). The total drug-related expenditures in Croatia make 0.2 percent of GDP.

The structure of total drug-related expenditure shown in Table 9 is indicative. It completely changes the first picture of labelled costs only. It turns out that law enforcement is one of the main pillars of drug policy in Croatia. Efforts in prevention and treatment, together with social reintegration are almost equally financed from the state budget (12 and 13 per- 
DRUŠ. ISTRAŽ. ZAGREB GOD. 23 (2014), BR. 3 STR. $407-425$

ŠVALJEK, S., BUDAK, J.: THE STRUCTURE OF...

TABLE 8
Total drug-related
expenditures of central
government units,
2009-2012 (plan),
HRK million

TABLE 9

Structure of drug policy expenditures in 2011 , in \% cent of total expenditures respectively). Harm reduction makes up only 2 percent of the total expenditures. The social reintegration program that is analysed separately in Croatia comprises a negligible part of the total drug-related expenditures ( 0.3 percent). This picture does not change even if somewhat larger financing planned in year 2012 is taken into account.

\begin{tabular}{|c|c|c|c|c|c|}
\hline Program & & 2009 & 2010 & 2011 & 2012(p) \\
\hline Prevention & & 83.5 & 80.9 & 87.8 & 87.2 \\
\hline Treatment & & 89.1 & 93.7 & 94.8 & 82.7 \\
\hline Social reintegration & & 2.2 & 2.2 & 2.1 & 2.9 \\
\hline Harm reduction & & 10.9 & 14.3 & 16.1 & 15.9 \\
\hline Law enforcement & & 520.0 & 521.9 & 537.2 & 507.9 \\
\hline Total expenditures & & 705.7 & 713.0 & 738.0 & 696.6 \\
\hline Program & Labelled & \multicolumn{2}{|c|}{ Unlabelled } & & Total \\
\hline Prevention & 30 & & 10 & & 12 \\
\hline Treatment & 55 & & 6 & & 13 \\
\hline Social reintegration & 3 & & 0.1 & & 0.3 \\
\hline Harm reduction & 8 & & 1.6 & & 2 \\
\hline Law enforcement & 4 & & 82 & & 73 \\
\hline
\end{tabular}

\section{CONCLUSIONS AND POLICY RECOMMENDATIONS}

After conclusion of the research on drug policy expenditures, labelled and unlabelled, and after the results have been assessed and allocated by drug policy program, we can conclude that the majority of public funds allocated to drug enforcement policy are spent on law enforcement, which is in line with similar studies carried out in other countries. Prevention has taken up a much lower proportion of funding even though it is deemed as the first priority of drug enforcement policy. Nonetheless, the share of drug policy expenditures aimed at prevention is relatively high in Croatia when compared to other countries. Drug treatment, on the other hand, has a relatively low share in the total drug-related public spending.

It is important to stress that there are many reasons why results presented in this paper should be taken and interpreted with due caution. Mainly, government spending on drug policy is spread across many different government levels, from central government through counties and cities and even municipalities. This makes it difficult to assess the total size of government spending on drug policy. The majority of spending is embedded within larger programs such as that of 
DRUŠ. ISTRAŽ. ZAGREB GOD. 23 (2014), BR. 3, STR. $407-425$

ŠVALJEK, S., BUDAK, J. THE STRUCTURE OF... policy expenditures from the expenditures for regular everyday operation. Also, once the size of drug policy expenditures is assessed, it requires a lot of communication with government institutions as well as many assumptions to identify to which type of program expenditures belong.

Our research was bound by the available data as well as lack of budget program evidence by central government $\mathrm{u}$ nits. As far as drug-related policy is concerned, the practice of budget evidence calls for improvements. Both central and local government budget planning should reflect the goals and objectives of strategic documents as well as particular programs. Unlabelled expenditures could never be evidenced as such in budgetary hard data, yet they could be carefully estimated by using the appropriate methodology which should be applied consistently and its outcomes could be regularly monitored for a longer period.

This new approach calls for the rethinking of unlabelled public drug expenditures by budget planners and policy makers who should refer to programs and strategic documents and associate institutions' regular work to a particular program: prevention, treatment and social reintegration, harm reduction, law enforcement. All this should lead to more precise estimates. Besides the issue of public financing information, there is a general lack of data needed to create effective drug combating policy measures and to monitor its outcomes. For example, national evidence of number of days drug addicts spend in treatment, expenditures by the type of treatment, costs of social care per addict, average number of imprisonment days of persons sentenced for drug offences and other important indicators for successful drug policy are missing in Croatia. Availability of data and pursuing the standardized methodology in monitoring the drug policy would probably help to identify other critical points, e.g. the higher level of coordination needed for more effective drug policy implementation. Unless effectiveness is measured against expenditures, policy recommendations are not possible and this leads us to the key policy recommendation: that the effectiveness of drug policy must be evaluated.

Conclusively, this is the first attempt to estimate unlabelled drug expenditures by program and therefore provides unique evidence of total drug-related public expenditures in Croatia. There are only a few countries with roughly estimated unlabelled drug expenditures, and categorization by programs is still missing. In line with the current initiatives from EMCDDA to encourage national monitoring of total national drug-related public expenditures by programs, this research should contribute to the developing of the standardized methodology in this field. 


\section{ACKNOWLEDGEMENTS}

This research was undertaken as a part of the project Public expenditures and the establishment of performance indicators in the field of combating drug abuse in the Republic of Croatia agreed between the Institute of Economics, Zagreb and Office for Combating Drug Abuse of the Government of the Republic of Croatia which has provided financial support for the project. The authors express appreciation for the reviewers' comments. The views and results presented in this paper, however are the authors' responsibility only.

\section{NOTES}

\section{REFERENCES}

${ }^{1}$ Current relevant documents are National Drug Control Strategy in the Republic of Croatia 2012-2017 and National Drug Control Action Plan in the Republic of Croatia 2012-2014. http://www.uredzadroge. $\mathrm{hr} /$ dokumenti/

2 For more information on the Project of Social Reintegration of Drug Addicts, see http://www.uredzadroge.hr/ovisnosti-i-vezane-teme/ projekt-resocijalizacije/o-projektu/

3 The economic definition of drug-related social cost as the sum of public expenditures, private expenditures and external expenditures borrowed by Vander Laenen et al. (2008) differs from the definition used by Single et al. (2001) in cost-of-illness guidelines for estimating the costs of drug abuse; the latter not including the private expenditures in the social costs of drug use.

${ }^{4}$ For explanation of the use of repartition keys, see Vander Laenen et al. (2008).

Berg, B. L. (1995). Qualitative research methods for the social sciences (2nd ed.). Boston: Allyn and Bacon.

Budak, J., Jurlina Alibegović, D., Slijepčević, S., \& Švaljek, S. (2013). Analiza javnih rashoda za praćenje ostvarivanja ciljeva u području suzbijanja zlouporabe droga u Republici Hrvatskoj [Analysis of public expenditure for monitoring achievement of the objectives in the field of combating drug abuse in the Republic of Croatia]. Zagreb: Ekonomski institut, Zagreb i Ured za suzbijanje zlouporabe droga Vlade Republike Hrvatske.

Costa Storti, C., De Grauwe, P., \& Reuter, P. (2011). Economic recession, drug use and public health, Editorial. International Journal of Drug Policy, 22(5), 321-325. doi:10.1016/j.drugpo.2011.07.009

Denzin, N. K. (1978). Sociological methods: A source book (2nd ed.). New York: McGraw-Hill.

European Monitoring Centre for Drugs and Drug Addiction (EMCDDA) (2013). European drug report 2013: Trends and developments, Luxembourg: Publications Office of the European Union. Available at http://www. emcdda.europa.eu/publications/edr/trends-developments/2013 
DRUŠ. ISTRAŽ. ZAGREB GOD. 23 (2014), BR. 3, STR. $407-425$

ŠVALJEK, S., BUDAK, J.: THE STRUCTURE OF..
European Monitoring Centre for Drugs and Drug Addiction (EMCDDA) (2008). Towards a better understanding of drug-related public expenditure in Europe. Lisbon: EMCDDA.

Greenfield, V. A., \& Paoli, L. (2012). If supply-oriented drug policy is broken, can harm reduction help fix it? Melding disciplines and methods to advance international drug-control policy. International Journal of Drug Policy, 23(1): 6-15. doi:10.1016/j.drugpo.2011.04.007

Institute of Economics, Zagreb (EIZ) (2013). Analiza javnih rashoda $i$ prijedlog pokazatelja rezultata $i$ ishoda za praćenje ostvarivanja ciljeva $u$ području suzbijanja zlouporabe droga u Republici Hrvatskoj [The study of public expenditures and the establishment of performance indicators in the field of combating drug abuse in the Republic of Croatia], January 2013. Available at http://www.eizg.hr/en-US/The-study-of-public-expenditures and-the-establishment-of-performance-indicators-in-the-field-ofcombating-drugabuse-in-the-Republic-of-Croatia-920.aspx

Lievens, D., Vander Laenen, F., Caulkin, J., \& De Ruyver, B. (2012). An analysis of the Belgian public expenditure study 'Drugs in Figures III': Exploring the potential roles for drug policy. Universiteit Gent Working Paper, 2012/771.

Miles, M. B., \& Huberman, A. M. (1994). An expanded sourcebook: Qualitative data analysis (2nd ed.). Thousand Oaks: Sage Publications.

Moore, T. J. (2008). The size and mix of government spending on illicit drug policy in Australia. Drug and Alcohol Review, 27(4), 404-413. doi:10.1080/09595230802093737

Office for Combating Drug Abuse of the Government of the Republic of Croatia: Projekt resocijalizacije ovisnika o drogama [Project of resocialization of drug addicts]. Available at http://www.uredzadroge.hr/ ovisnosti-i-vezane-teme/projekt-resocijalizacije/

Ramstedt, M. (2006). What drug policies cost. Estimating drug policy expenditures in Sweden, 2002: Work in progress. Addiction, 101(3), 330-338. doi:10.1111/j.1360-0443.2005.01344.x

Reuter, P., Ramstedt, M., \& Rigter, H. (2004) (Eds.). Developing a framework for estimating government drug policy expenditures. Lisbon: EMCDDA.

Reuter, P. (2006). What drug policies cost. Estimating government drug policy expenditures. Addiction, 101(3), 315-322. doi:10.1111/j.1360-0443. 2005.01336.x

Rigter, H. (2006). What drug policies cost. Drug policy spending in the Netherlands in 2003. Addiction, 101(3), 323-329. doi:10.1111/j. 13600443.2006.01337.x

Sakoman, S. (2008). Društvo bez droge? Hrvatska nacionalna strategija [Drug-free society? Croatian National Strategy], 3rd Edition, Zagreb: Institute of Social Sciences Ivo Pilar.

Sakoman, S. (2000). Substance abuse in the Republic of Croatia and National Program for Drug Control. Croatian Medical Journal, 41(3), 270-286.

Silverman, D. (2006). Interpreting qualitative data (3rd ed.). Thousand Oaks: Sage Publications.

Single E., Collins, D., Easton, B., Harwood, H., Lapsley, H., Kopp, P., \& Wilson, E. (2001). International guidelines for estimating the costs of 
DRUŠ. ISTRAŽ. ZAGREB GOD. 23 (2014), BR. 3 STR. $407-425$

ŠVALJEK, S., BUDAK, J.: THE STRUCTURE OF... substance abuse - 2001 Edition. Available at http://drogfokuszpont.hu/ wp-content/uploads/kokk_ped_guidelines_2001.pdf

Strang, J., Babor, T., Caulkins, J., Fischer, B., Foxcroft, D., \& Humphreys, K. (2012). Drug policy and the public good: Evidence for effective interventions. The Lancet, 379(9810), 71-83. doi:10.1016/S01406736(11)61674-7

Trautmann, F., Braam, R., Keizer, B., \& Lap, M. (2011). Evaluation of the National Drug Strategy of the Republic of Croatia (2006-2012). Trimbos Instituut, Government of the Republic of Croatia, TAIEX, Office for Combating Drug Abuse and EMCDDA. Available at http://www. trimbos.org/projects/research-monitoring-and-policies/evaluationof-the-croatian-national-drug-strategy

Vander Laenen, F., Vandam, L., De Ruyver, B., \& Lievens, D. (2008). Studies on public drug expenditure in Europe: Possibilities and limitations. Bulletin on Narcotics, 60(1), 27-43.

\section{Struktura javnih rashoda za suzbijanje zlouporabe droga u Hrvatskoj: koji su prioriteti?}

Sandra ŠVALJEK, Jelena BUDAK

Ekonomski institut, Zagreb

Odgovori nacionalne politike na sve veći problem droga očituju se u financiranju niza aktivnosti suzbijanja zlouporabe droga. $U$ ovom se radu analiziraju javni rashodi za suzbijanje zlouporabe droga u Hrvatskoj od 2009. do 2012. godine, s ciljem utvrđivanja ukupnih, i u okviru toga nespecificiranih, javnih rashoda na području suzbijanja zlouporabe droga. Glavni cili istraživanja jest razviti metodologiju procjene i alokacije nespecificiranih rashoda prema vrsti programa suzbijanja zlouporabe droga. Procijenjeni ukupni rashodi su prema Reuterovoi podieli alocirani na prevenciju, tretman i socijalnu reintegraciju, smanjenje štete $i$ kazneno-represivni sustav. Rezultati pokazuju koje vrste programa za suzbijanje zlouporabe droga javne institucije u Hrvatskoj najviše podržavaju, mjereno udjelom izdataka za pojedine programe u ukupnim javnim rashodima. Primijenjena metoda može pridonijeti razvoju međunarodnih metodoloških standarda, a rezultati se mogu iskoristiti za buduće praćenje javnih rashoda i učinkovitosti mjera politike suzbijanja zlouporabe droga u Hrvatskoj.

Ključne riječi: troškovi suzbijanja zlouporabe droga, prevencija, smanjenje štete, tretman, kazneno-represivni sustav 